\title{
Using Mobile Learning to Enhance Pre-Service Teachers' Participation in Distance Education English Tutoring Sessions ${ }^{1}$
}

\section{Aprendizaje Móvil para mejorar la participación de los docentes en formación en sesiones tutoriales en Educación a Distancia.}

\author{
Angélica María Carvajal Téllez ${ }^{2}$ \\ Escuela Normal Superior Sor Josefa del Castillo - Chiquinquirá \\ Universidad Santo Tomás \\ angelica.carvajal@ustadistancia.edu.co \\ Yolanda Duarte Medina ${ }^{3}$ \\ Universidad Santo Tomás - Chiquinquirá \\ yolandaduarte@ustadistancia.edu.co
}

Received: November 19, 2016

Accepted: January 10, 2017

How to cite this article (APA, 6th ed.): Carvajal-Téllez, A., and Duarte-Medina, Y. (2017). Using Mobile Learning to Enhance Pre-Service Teachers' Participation in Distance Education English Tutoring Sessions. Enletawa Journal, 10 (1), 69 - 84

1 Report on a Pedagogical experience.

2 Angélica María Carvajal Téllez is a cathedra English Professor at Universidad Santo Tomas and a full time teacher at Escuela Normal Superior Sor Josefa del Castillo y Guevara in Chiquinquirá - Boyacá. She holds a B.A. in Modern Languages from Universidad Pedagógica y Tecnológica de Colombia and a M.A. in Foreign Language Teaching from UPTC. Her current research interests cover assessment, evaluation and language teaching.

3 Yolanda Duarte Medina is a full Professor at Universidad Santo Tomás in Chiquinquirá, Boyacá. She holds a B.A. in Philology and Languages, English from Universidad Nacional de Colombia and a M.A. in Virtual Learning Environments from Universidad de Panamá. Her current research interests cover ICT to teach languages and new methodologies for teaching English. 


\begin{abstract}
This article is the result of a small-scale research study aimed to enhance pre-service teachers' participation in distance education tutoring sessions at the Universidad Santo Tomas, CAU (University Assistance Centre) in Chiquinquirá. The study was carried out by implementing mobile learning, specifically a mobile learning application called Kahoot. When carrying out online activities, in particular grammar games and oral discussions that involved the use of smart phones in tutorial sessions, the pre- service students were more engaged, and their participation increased greatly. Moreover, it is meaningful for students to improve their English language competence by activating their use of digital skills. Some of the benefits of mobile learning are flexibility and personalized learning activities, which try to address the needs of individual learners. This study showed that mobile learning promotes active participation, as well as knowledge construction and collaborative learning. It also creates a positive atmosphere and exposes students to innovative learning environments.
\end{abstract}

Key words: Mobile Learning, Distance Education, Pre-service teachers.

\title{
Resumen
}

Este artículo es el resultado de un estudio de investigación a pequeña escala cuyo propósito era mejorar la participación de los estudiantes de la licenciatura en lengua extranjera en las tutorías de inglés, en la Universidad Santo Tomás, CAU (Centro de Atención a Usuarios) de Chiquinquirá (Educación a Distancia), mediante la implementación del aprendizaje móvil, especialmente el uso de la aplicación de aprendizaje llamada Kahoot. El uso de celulares para participar en juegos de gramática en línea y discusiones evidenció que los estudiantes de la licenciatura se involucran más durante las tutorías y su participación aumenta considerablemente. Además, el aprendizaje se hace más significativo cuando sus habilidades digitales se ponen en práctica y se utilizan para aprender y mejorar su competencia en el idioma inglés.

Algunos de los beneficios del aprendizaje móvil son la flexibilidad y la personalización de las actividades, lo cual busca satisfacer las necesidades particulares de cada estudiante. Este estudio reveló que el aprendizaje móvil promueve la participación activa, pero también la construcción del conocimiento y el aprendizaje colaborativo. También crea un ambiente positivo para aprender y expone a los estudiantes a entornos de aprendizaje innovadores.

Palabras clave: Aprendizaje móvil, Educación a distancia, Docentes en formación. 


\section{Introduction}

This study was developed with a group of pre-service teachers who belong to the distance education Bachelor's in English as a foreign language program at a private university. Students were at an intermediate English level, meaning that they are independent users of the language and can express themselves in familiar situations regularly encountered at work or at the university. They can also describe experiences and briefly give reasons and explanations for opinions and plans.

This pedagogical initiative aimed to enhance students' participation in long distance English tutoring sessions using a mobile learning application (app) called Kahoot. The idea started when we asked ourselves about possible ways to engage students and motivate them to participate more actively. Considering that the English classes are meant to respond to the necessities of the students, we began to conduct a diagnosis. First, we observed students' performance, attitudes and interactions during English tutorial sessions. We noticed that most of the students seemed reluctant to participate in oral activities, such as discussions or debates, and they were not so enthusiastic when practicing grammar. After this diagnosis, we decided to give the students a questionnaire (survey) to better understand which ICT (Information and Communication Technology) tools they considered useful in the classroom, which technological devices were the most used, and what resources were uti- lized for research when answering teachers' posts on the online platform. When checking the information provided by the students, most of them expressed that they would like to use mobile apps to practice English.

This analysis allowed us to design an action plan that would combine the use of the mobile app, Kahoot, with traditional face to face tutoring sessions during one semester. Kahoot is a game-based learning platform that allows teachers to administer quizzes, surveys and discussions. With this app, the whole class can participate in real time. Students answer the questions projected on the screen by using their smart phones or tablets.

By implementing Kahoot, we were able to create, customize and adapt grammar exercises proposed by the course book. Students had to practice grammar by answering multiple choice questions or unscramble sentences on their own devices in a given time limit. They received immediate feedback after each question, and they gained points according to how quickly and correct their answers were.

This app let us create discussions by posing controversial and debatable questions taken from the course book readings. Students participated by choosing one of the questions on their smart phones. Then, they saw the most popular questions chosen on the screen. We generated a discussion around the questions chosen. This was done in order to encourage oral participation among the pre-service teachers.

Finally, we analyzed the data for common patterns in students' answers, attitudes during the tutoring sessions, 
and their performance during the lessons. This information provided a great wealth of understanding in order to present preliminary results.

This kind of project exposes pre-service teachers to experience new teaching and learning tools. These activities have the potential to enhance students' English learning through dynamic and engaging activities that catch their attention and promote active participation, knowledge construction, and collaborative learning. Additionally, it creates a positive atmosphere. This project also served as a research experience to reflect on our teaching practice and to inspire other teachers to use mobile tools to create more meaningful and enjoyable learning environments.

\section{Context and Setting}

We conducted this study with 15 university students, 7 women and 8 men, between the ages of 18 and 35. Most of them are from Chiquinquirá, and although others are from nearby towns and rural areas of Boyacá and Cundinamarca, such as Saboyá, Simijacá and Ubaté. Their socioeconomic strata range from 1 (low) to 3 (middle) according to the Colombian system of stratification primarily based on living conditions. What this means is that students are considered in the poor to low middle class. They are in their sixth semester of the Bachelor in English as a Foreign Language program via distance learning. They are taking the Intermediate English I course, therefore, their English level is B1 according to the Common
European Framework of Reference for Languages

Most of the students enrolled in distance education because they live far away from the main university campus, or because they do not have enough time to attend regular classes every day due to their full-time jobs and family responsibilities. Students attend tutoring sessions only on Saturdays. They complete assignments posted on the university platform during weekdays, and they also complete assignment in the online workbook. Each tutoring session lasts 2 hours. In this institution, there are two types of teachers, also called tutors, the national and regional ones. The national tutors are in charge of creating all the content in the platform, monitoring students' work and guiding them using asynchronous and synchronous communication. On the other hand, regional tutors have face to face classes with students. They are in charge of contextualizing the topics to the particular characteristics of the regional context, as well as providing explanations about the content presented in each of the units of the course book and guidance on how to develop the corresponding tasks.

\section{Theoretical constructs}

According to Soykan and Uzunboylu (2015), distance learning has been improving from letter learning, students received lessons and exercises by post, to mobile learning. Because of this, one of our goals was to encourage other teachers to pursue mobile learning in their classrooms. Nowadays, with the inclusion 
of ICT tools in the teaching and learning process, schools and universities are trying to implement new methodologies that include portable devices such as cell phones that can enrich students' learning process.

Herrera, Cruz, and Sandoval (2014) presented a qualitative action research aimed to implement activities entailing the use of portable devices (cell phones, tablets, laptops, and netbooks) in order to learn their impact. These applications included a learning management system that resembled a social network, a live interaction application, and an online dictionary. It was found that students were able to productively use these devices as learning tools plus they expressed comfort and interest in using them.

In another Colombian study, the interaction between a tutor and her students was studied during online tutoring sessions (OTS) in the ALEX Virtual English Program at the Universidad Nacional de Colombia in Bogotá. This reciprocal action allowed the participants to establish new ways of interaction. Riveros (2009) mentions that the main interaction between the tutor and the learners consisted of double-way dynamics, as a cooperative process in which both tutor and student benefit each other from the experience. In our case, these dynamics allowed students and tutors to interact in an active way, making use of better classroom strategies.

The main constructs that lead this study are mobile learning, pre-service teachers' participation and tutorial support in distance education.

\section{Mobile learning}

Mobile learning (M-learning) is thought to be the predecessor of what is known as electronic learning (e-learning), and CALL (Computer Assisted Language Learning). These concepts lead to MALL (MobileAssisted Language Learning). The urgent need to include innovative approaches in order to involve students' interests inside the classroom, let us recognize that the use of mobile learning and Personal Digital Assistants (PDAs) can be successful teaching tools. According to Mishra (2007) one of the advantages of instruction using digital material is that it can reach learners wherever they are, because they can use portable devices to revise it.

Kukulska and Traxler (2005) claimed that pedagogy of mobile learning can be broadly categorized into: didactic content, discursive interactions, generic academic support, subject-specific, and guidance support (p. 40). They concluded that mobile learning can be spontaneous, portable, personal, informal and situated, which means that students create meaning from daily life activities.

Ramsden (2005) highlights two important issues about mobile learning:

(a.) There is a need to design and author materials for PDAs by maximizing the accessibility and minimizing the need for re-purposing existing materials, like Blackboard- based course materials.

(b.) There is a need for appropriate pedagogical designs to harness the unique potential benefits of mobile learning.

Given these issues, Kahoot was used as a tool in which tutors combine different teaching resources, such as SMS (text mes- 
saging), for skills test, collecting feedback, learning from audio (iPods, MP3 player, Podcasting), and Java-based quizzes.

\section{Distance Education}

Distance education or distance learning uses technology to deliver instruction to students who cannot attend regular classes because they live far away from the university, or they do not have time to go to classes due to work or family responsibilities. In distance education, students use a learning platform to learn. They visit the university from time to time to receive personal guidance as a mean of facilitating their learning process. During tutorial sessions, the role of the Tutor is to facilitate the interaction among students and foment knowledge construction and collaborative work. This means that students not only gain new knowledge from the tutor, but also from their peers.

The instructional organization at this private distance university allows pre-service teachers to learn by using communication through technological means. Students visit the Chiquinquirá CAU for English tutoring sessions on the weekends, but they also have asynchronous on-line scheduled guidance during the week with their national or regional tutors. During the tutoring sessions, pre-service teachers play an active role when tutors provide educational spaces that engage participants to speak freely. Moore and Kearsley (2011, p. 2) stated that asynchronous learning can also be understood as distributed learning, characterized by its availability at any place and time. Pre-service teachers tend to participate more from home than during the tutoring sessions. This justifies the need to listen to the students' needs and voices when receiving tutoring.

\section{Research design}

This study can be considered an action research study because it investigates a real university situation in order to understand and improve quality of action and instruction (Johnson, 2002). In this particular case, we identified a problematic situation in which pre- service teachers did not actively participate in tutorial sessions. As an action plan, we decided to implement the use of mobile learning as a teaching strategy, which could engage students and make them feel more comfortable in participating.

This study is also a form of self-reflective enquiry undertaken by the participants in social situations in which pedagogical practices are carried out (Kemmis, 1988, as cited in Loraine Loraine, Hughes, ad Tight, 2005, p. 96-97). It does not seek to generalize ideas beyond our research context because it centers on the processes and outcomes of this investigation. Since pre-service teachers shared ideas and provided sug-gestions to one another, action research was evident because it is the study of a social situation with a need to improve the quality of action within it (Elliott, as cited in Loraine Hughes, and Tight, 2005, p, 96-97).

\section{Research Question}

How can mobile learning enhance pre- 
service teachers' participation in English tutoring sessions enrolled in a distance education?

\section{Data gathering}

Data sources included in this research were pre-service teachers' surveys, students' journal and tutors' observation.

Participant observation. This type of observation was carried out by the teachers who were also the researchers. We used this instrument to check students' attitudes and feelings during tutoring sessions. Through observations, we contrasted students' attitudes when they attended tutorial sessions in which we did not implement mobile learning with ones in which we did. Observations also allowed us to determine if students enjoyed the tutorials by looking at their attitude and listening to their positive comments about the classes.
Journals/diaries. These sources of information were very pertinent in keeping track of students' reflections and perceptions of their participation during the tutoring sessions. By reading students' journals, we understood how effective they thought the methodology was, and how safe and confident they felt inside the classroom. They also included information about how the tutoring sessions could be improved through innovative methodologies and technological devices.

Questionnaires. They allowed students to focus on specific questions (open, close and multiple choice) regarding key aspects, such as internet tools, teaching approaches and technological devices. These provided us with valuable information about preservice students' needs, preferences and opinions about the tutoring sessions.

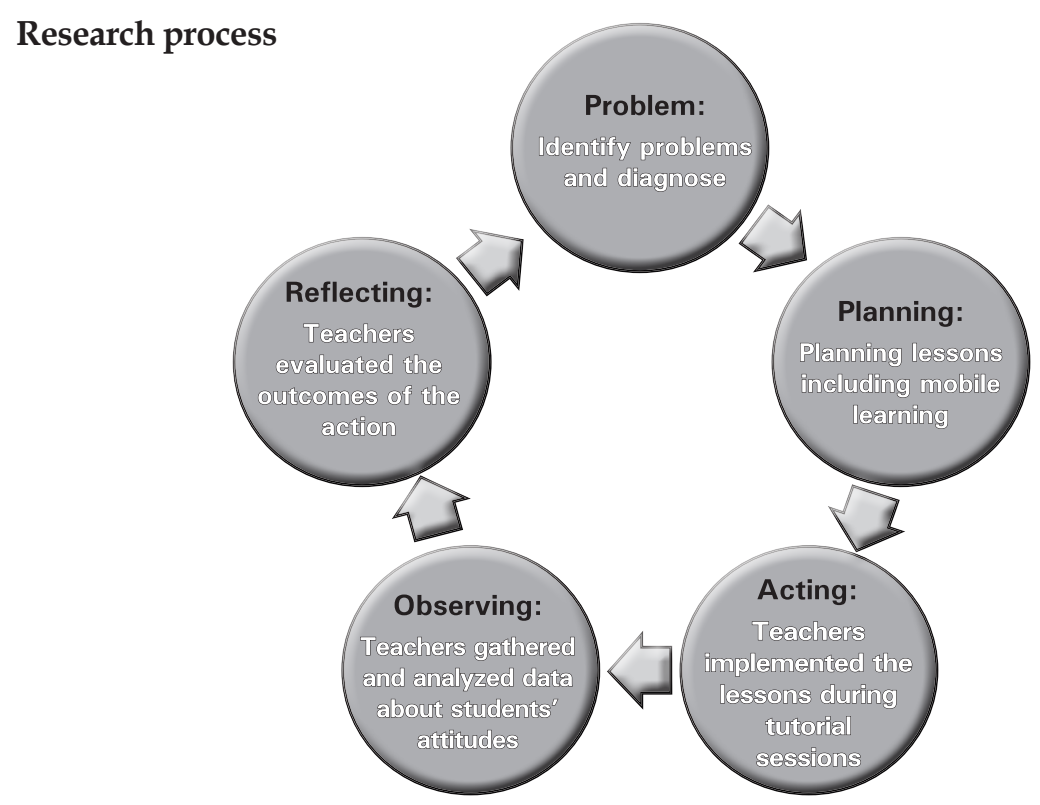

Graph 1: Research cycle 


\section{Diagnostic Stage}

Once we identified the problematic issue, we made a diagnosis by applying a questionnaire to gather information about students' internet tools and mobile apps preferences. Students expressed that they mainly preferred emails, chats and social networks, as well as apps like Duolingo or online dictionaries. Students also made explicit that they wanted to have methodologies that included the use of cell phones inside the classroom. We had observed students' performance in regular English tutorial sessions, and we realized that students lacked interest when developing grammar and oral tasks. Thus, the diagnosis allowed us to design an action plan to implement mobile learning as a teaching strategy to foster pre-service teachers' participation.

\section{Planning and Action Stage}

After getting the results from the diagnostic stage, we designed an action plan. We created six lesson plans in which we included activities using the Kahoot app. We followed the PPP lesson plan structure (Presentation, Practice and Production). Each lesson consisted of a warm up, a presentation of the topic, a controlled practice using grammar games with Kahoot, and finally a freer practice or production stage. Once we finished developing the lesson plans, we started implementing them during the tutoring sessions. At the beginning, students had to become familiarized with the application by doing some sample exercises. Afterwards, we asked them to participate in grammar games and discussions by using their cell phones. Students could work individually or in groups. This demonstrates the social component that this application has when promoting exchange and collaboration among students.

\section{Analysis of data}

We analyzed the data gathered by looking for common patterns in students' answers. This analysis attempts to present answers to the questions we posed. It includes the framework of data analysis, a data display contrasting the questions with the categories, and the results from the chosen instrument.

First of all, we transformed the raw data from the observation. Additionally, we wrote comments to enrich the analysis. We codified the information to find commonalities, and we read and re-read to find patterns and establish relations. Then, we identified the following three broad categories: constructing knowledge, learning collaboratively and creating a positive atmosphere. After that, we returned to the raw data to reconstruct the matrix categories. In order to validate the data, we used data triangulation and time triangulation, in which two instruments used over a period of time can be compared and analyzed to identify common factors confirming the progress achieved (Burns, 1999). Timetriangulationindicatescollection of data at different times to determine if similar findings occurred (Kimchi, Polivka, \& Stevenson, 1991).

The four categories identified are depicted in Table 1. Afterward, there is a detailed description of each one of them. 


\begin{tabular}{|l|l|l|}
\hline & \multicolumn{1}{|c|}{$\begin{array}{c}\text { MAIN } \\
\text { CATEGORY }\end{array}$} & SUB-CATEGORIES \\
\hline $\begin{array}{l}\text { What are the benefits of } \\
\text { using Mobile Learning as } \\
\text { a teaching methodology } \\
\text { during tutoring sessions }\end{array}$ & $\begin{array}{l}\text { Promoting active } \\
\text { participation through } \\
\text { in distance education? }\end{array}$ & Constructing Knowledge \\
\cline { 3 - 3 } & & Learning Collaboratively \\
\cline { 2 - 3 } & & Creating a positive atmosphere \\
\hline
\end{tabular}

Table 1. Matrix categories

\section{Mobile Learning promotes active participation}

The collected data made evident that mobile learning fosters students' participation because they enjoy practicing the language through play. Students do not like monotonous tasks, so they become very enthusiastic about activities which challenge not just their knowledge, but their ability to analyze a question during the time limit. Abdullah, Abu Bakar, and Haizan (2012) stated that participation can occur in the following circumstance: when students can be influenced by sociocultural, cognitive, affective, linguistic, or environmental factors. This circumstance often leads to student participation and interaction with other students, while instructors speak only at designated times (p. 516). In this case, the use of the cell phone as a learning tool makes students feel confident enough to speak and share their experience with their classmates. The role of the tutor shifts to a promoter of the language and motivator of participation. This category is supported by Pre- service teacher 6, whose answer states:

Pre-service teacher 6: The use of mobile learning motivates us to communicative more with our classmates and lets us participate in an active way.
Students participated effectively and they expressed positive attitudes towards the use of mobile learning apps. According to Davis (2009), students' enthusiasm and willingness to participate in a classroom through verbal engagements will create a conducive classroom environment. Some arguments that support the active and enthusiastic role of participants were evident in some pieces of Pre-service Journals:

Pre-service teacher's Journal 8: Using the app, learning is easier and more entertaining.

Tutor's observation format: Participants seem to be affective engaged because the use of mobile learning relates to their interests, attitudes, and motivations. Since now, we as tutors, must meet what students are expected to be able to know, do, or value as a result of engaging in the learning process.

\section{Constructing Knowledge}

The second category we found after data analysis is the strengthening of knowledge construction. The interaction with the Kahoot app facilitated discussions, so students started expressing their opinions and listening to their classmates' points of view. Results also showed that students were primarily sharing knowl- 
edge with their classmates and involving cognitive process of "understanding" during the discussions.

Tutor's observation format: Starting a discussion through Kahoot allows participants to begin a discussion and to participate on it by giving their opinions and extend their range of words and accuracy of the language. For them it was really easy to share knowledge with their pairs.

Mobile applications can also enhance knowledge construction by involving students in games and discussions in which they ask their classmates for support. Students become part of collaborative knowledge construction processes, not by obligation, but rather in a free, participative environment. Through mobile learning students perceived interaction itself to be rewarding (Kimmerle, Moskaliuk, Oeberst, and Cress, 2015), and they had an opportunity to learn from different sources, such as their classmates and mobile applications.

\section{Collaborative learning}

Collaborative learning (CL) is defined as an educational approach in which a group of students work together to solvea problem, complete a task, or create a product. The concept of CL is largely rooted in Vygotsky's sociocultural theory (SCT), which views learning as an inherently social process activated through the Zone of Proximal Development (ZPD) (Dillenbourg, 1999, as cited in Lin, 2015). Vygotsky's sociocultural views have contributed significantly to social constructivist epistemology, and they highlighted how learning is mediated in accordance with the context and experiences among peers.

During the lessons and from the interviews and journals, we found that pre-service teachers think that using mobile learning promotes team work (Collaborative Learning) and opens opportunities to share knowledge and interact with their peers. This can be seen in the following pre-service teachers' journals:

Pre-service teacher 1: "I think mobile learning is very important because it promotes interaction and competition among classmates."

Pre-service teacher 2: "I think the class was interesting because we shared knowledge and we learnt about apps for learning English."

The pre-service teachers' comments showed how competitive language mobile games foster collaboration and team work. Students share their knowledge as a way to reach a common goal, which means to them being the winners of the game. It means that the success of one student depends largely on other students. That is, one student helps others to be successful as well, and in this interaction learning just happens (Lin, 2015).

\section{Creating a positive atmosphere}

Classroom atmosphere or climate refers to the prevailing mood, attitudes and tone that students feel in the classroom. It has to do with the students' perceptions of the rigor of the class, their interactions with their instructor and class peers, and their involvement in the class 
(Reid \& Radhakrishnan, 2003, as cited in Barr, 2016 p. 1). According to Fraser and Treagust (as cited in Barr, 2016 p. 2), there are seven dimensions that contribute to a positive classroom atmosphere: personalization, involvement, student cohesiveness, satisfaction, task orientation, and innovation.

From the surveys, we found out that mobile learning strengthens two of these dimensions: satisfaction, which means that students enjoy the class and innovation, which refers to the unique teaching methods and techniques used by the teacher in class. We can verify these two dimensions in the following pre service students' answers to the question below:

Do you think mobile learning helps to create a positive atmosphere into the English classroom?

Pre-service teacher 1: "Yes, the class is more relaxed." (Satisfaction)

Pre-service teacher 2: "Yes, students are more motivated." (Satisfaction)

Pre-service teacher 3: "Yes, we are very interested in the class and this is funnier." (Satisfaction) Pre-service teacher 4: "Yes, the use of technology creates a motivational environment" (Innovation)

Pre-service teacher 5: "Yes, if you are happy, you understand the topics better." (Satisfaction)

These findings suggest that the preservice teachers believe that a positive learning atmosphere is greatly enhanced through the use of mobile learning, which motivates pre- service teachers to participate and reduces their anxiety allowing them to learn in a fun and relaxed way.

\section{Findings and conclusions}

This study demonstrates that mobile learning provides an alternative option for teachers who want to promote or maintain active participation from their students during tutoring sessions at CAU Chiquinquirá. By using mobile applications, students showed a higher level of engagement developing online grammar activities, as well as participating in discussions. This kind of learning is an efficient method to motivate pre-service teachers to participate more actively during tutorial sessions because it creates a positive environment, free of anxiety or fear of making mistakes. Learning becomes enjoyable and free of judgment. It also facilitates collaborative learning and knowledge construction.

This type of research contributes to the development of awareness on the importance of motivating students in English classes by using different kind of teaching strategies. Using mobile phones in class continues to be a taboo for many teachers who still consider these devices as distractors rather than learning tools. It is important to rethink how these kinds of technological devices can be useful tools in creating meaningful lessons and opportunities to extend and consolidate students' learning process outside the classroom.

Nowadays, students use portable devices to support their learning, and as teachers we need to consider this reality. When using these devices during tutoring sessions, students felt that there was a relationship between the real world and 
the classroom. Lessons which implement mobile learning encourage a two-way interaction: tutor-students and studentstudent, making everyone feel part of a team. The only goal is to participate and receive/provide feedback as a way to keep improving.

As researchers, this project offered us the opportunity to gain experience in understanding previous studies that lead us to create our own initiatives. As tutors we must engage ourselves and students in research processes that analyze evident issues that surrounding us. We were able to generate meaningful discussions and alternative interactions inside the classroom. This research exercise led the participants and researchers to analyze dynamics and strategies typical of distance education, such as: online media, online environments, face-to-face sessions, oral presentations, and collaborative work. This also provided scenarios for students to discuss and reflect upon the learning process. At the same time, we promoted a research culture inside the subject of study.

Engaging in language research provides pre-service teachers with an ongoing source of one-on-one mentorship which gave way to models for further proposals. This study also strengthens collaborative work among mentor tutors and students by taking advantage of longdistance education models in terms of time and mediation.

\section{References}

Abdullah, M., Abu, B. N., and Haizan, M. (2012). Student's participation in class- room: What motivates them to speak up? Procedia, Social and Behavioral Sciences, 51, 516-522. Retrieved from https://www.researchgate.net/publication/ 257716731_Student's_Participation_in_ClassroomWhat_Motivates_them_to_Speak_up.

Barr, J. (2016). Developing a positive classroom climate. IDEA, pp. 1-3.

Burns, A. (2003). Collaborative action research for language teachers. USA: Cambridge University Press.

Davis, B. (2009). Tools for teaching. San Francisco: Jossey-Bass.

Fung, Y. and Carr, R. (2000). Face-to-face tutorials in distance learning system: Meeting student needs. Open Learning, 15(1), 35-46.

Herrera, L., Cruz, M., and Sandoval, M. (2014). Using personal portable learning tools in the English class. HOW, A Colombian Journal for Teachers of English, 21(2), 74-93.

Johnson, A. (2002). What every teacher should know about action research. Boston, MA: Pearson Education, Inc.

Karmila, I., Goodwin, R., and Mooney, C. (2015). Teachers and mobile learning perception: towards a conceptual model of mobile learning for training. Procedia, social and behavioural sciences, 176, 425-430. Retrieved from https://www. sciencedirect.com/science/article/pii/ S1877042815005297

Kimchi, J., Polivka, B., and Stevenson, J. (1991). Triangulation: Operational 
definitions. Nursing Research, 40(6), 364-366.

Kimmerle, J., Moskaliuk J., Oeberst, A., and Cress, U. (2015). Learning and collective knowledge construction with social media: A process-oriented perspective. EducPsychol, 50(2), 120-137.

Kukulska-Hulme, A. and Traxler, J. (2005). Mobile Learning: A handbook for educators and trainers. London and New York: Routledge.

Lin, L. (2015). Investigating Chinese HE EFL classrooms: Using collaborative learning to enhance learning. Berlin Heidelberg: Springer.

Loraine. B., Hughes, C., and Tight, M. (2005). Cómo se hace una investigación. (n.p): Fondo Editorial Gedisa.

Mishra, S. (2007). Mobile Learning: A handbook for educators and trainers. Indira Gandhi National Open University. Retrieved from: http:/ / www. irrodl.org/index.php/irrodl/article/ view $/ 437 / 877$

Moore, M. and Kearsley, G. (2011). Distance Education: A Systems View of Online Learning. Cengage Learning. Retrieved from: https://books.google. com.co/books?id=dU8KAAAAQBAJ\&printsec $=$ frontcover \&hl=es\&source=gbs_ge_summary_r\&cad $=0$ \# $\mathrm{v}=$ oneage $\& \mathrm{q} \& \mathrm{f}=$ false

Pineda-Hoyos, J. (2014). Social networking sites in the classroom: Unveiling new roles for teachers and new approaches to online course design. Íkala, Revista de Lenguaje y Cultura, 19(3), 269-283.
Riveros, M. R. (2009). Interaction in online tutoring sessions: An opportunity to knit English language learning in a blended program. Profile, 11, 117 -134.

Soykan, E., and Uzunboylu, H. (2015). The view of published articles on mobile learning area in EBSCO database. Procedia - Social and Behavioral Sciences, $710-717$. 


\title{
APPENDIXES
}

Appendix 1: Questionnaire

\begin{abstract}
USING MOBILE LEARNING TO ENHANCE PRE-SERVICE TEACHERS' PARTICIPATION IN ENGLISH TUTORING SESSIONS AT DISTANCE EDUCATION.
\end{abstract}

\section{PRE- SERVICE TEACHERS SURVEY}

OBJECTIVE: This survey is aimed to collect general information about enhancement of Preservice Teachers' participation using mobile learning in English tutoring sessions at Distance education.

\section{DATE:}

1. Do you think mobile learning is playing an important role English language learning? Yes Don't know

2. What mobile devices do you have now?
I Pad ___ Tablet type device __ Smartphone __ Portable Computer
None of these
Other (please specify)

3. Have you ever used your mobile device as a teaching or learning tool?

Yes No _ If yes, how?

4. Could you use free mobile learning content with your students?

Yes No

If yes, please explain how?

5. Do you use your mobile device to develop your own teaching?

Yes No

If yes, how?

6. Do you think mobile learning promotes your active participation in English classes? Yes No __ how?

7. Do you think your knowledge construction can be favored by the use of mobile learning? Yes No how?

8. Do you think the implementation of mobile learning activities enhance collaborative work? Yes No how? 
9. Do you think mobile learning helps to create a positive atmosphere into the English classroom? Yes No how?

10. What other teaching- learning strategies would you include in your English classes?

\section{Thanks for your collaboration.}

This instrument to collect information was adapted from Peachey, N (2011) in Mobile Learning in ELT 2011Friday retrieved from: http://www.deltapublishing.co.uk/development/survey-mobilelearning-in-elt- 


\section{Appendix 2: Student's Journal form}

\section{USING MOBILE LEARNING TO ENHANCE PRE-SERVICE TEACHERS' PARTICIPATION IN ENGLISH TUTORING SESSIONS AT DISTANCE EDUCATION}

\section{PRE- SERVICE TEACHERS REFLECTIVE JOURNAL}

OBJECTIVE: This pre-service reflective journal is aimed to collect general information about enhancement of Pre-service Teachers' participation using mobile learning in English tutoring sessions at Distance education.

After the development of this workshop, write a complete reflection of the process of using mobile learning into your English classes.

\section{NAME:}

DATE: 